\title{
FIELD AND LABORATORY STUDIES ON THREE EGGPLANT CULTIVARS TO EVALUATE THEIR RELATIVE SUSCEPTIBILITY TO SOME PIERCING SUCKING PESTS WITH RELATION OF LEAF CONSTITUENTS

\author{
Azouz, H. A.; E. M. A. Yassin; Mariam, A. El-Sanady and \\ Aziza, M. Abou-Zaid \\ Plant Protection Research Institute, A.R.C., Dokki, Giza, Egypt
}

\begin{abstract}
Field and laboratory studies were carried out to evaluate three eggplant cultivars, long black (Anan), white long (Soma) and spherical black (classic) for their relative susceptibility to spotted spider mite, Tetranychus urticae Koch, whitefly, Bemisia tabaci (Gennadius), aphid, Aphis gossypii Glover and Jassid, Empoasca lybica de-Berg infestation. The obtained results showed that spherical black cultivar was the most susceptible to spider mites, aphid and whitefly, while black cultivar was lowest level infestation by the tested sucking pests. Obtained data cleared that there were significant differences between eggplant cultivars and piercing sucking pests, which may be affected by plant leaf phytochemical constituents; total amino acids, total lipids, total carbohydrates, sodium, potassium, phosphorus, calcium, chloride and nitrogen, therefore, sodium, potassium, chloride, magnesium contents were negatively correlated with population density of different piercing sucking pests. On the other hand, total amino acids, lipids, carbohydrates, protein and nitrogen positively correlated with different piercing sucking pests.
\end{abstract}

\section{INTRODUCTION}

Eggplant, Solanum melongen $\mathrm{L}$. is one of the most important solanaceous crops. It is a good source of nutrients, minerals, antioxidants, vitamins, dietary fiber and body building factors and proteins (Matsubara et al., 2005). One hundred grams of fruit contains $0.7 \mathrm{mg}$ iron, $13.0 \mathrm{mg}$ sodium, $213.0 \mathrm{mg}$ potassium (Nonnecke, 1989), $12.0 \mathrm{mg}$ calcium $26.0 \mathrm{mg}$ phosphorus, $5.0 \mathrm{mg}$ ascorbic acid and 0.5 International Units of vitamin $A$ and provides 25.0 calories (Tindall, 1978). Ninety percent of production comes from five countries; china produces 24.5 million tons followed by India 10.6 and Egypt come in the third by 1.2 million tons per year. About 1.7 million hectares are devoted to cultivate eggplant in the world (FAO, 2010). Eggplant grows in temperate climates, so it is subjected to many pests as the two spotted spider mite, Tetranychus urticae Koch, the whitefly, Bemisia tabaci (Gennadius), Jassid, Empoasca lybica and aphid Aphis gossypii (Glover). These pests cause great damage to the plants. So, the screening of susceptibility of different cultivars against pests may help in the breeding of resistance varieties. The chemical constitution of the host plant may influence fecundity, egg viability and the mortality and the rate of development of immature stages as the leaf structure has been showed to be related to pest damage or to symptoms commonly associated with damage. The highest density of phytophagus mites occurred on leaves which, in addition to having higher total nitrogen content, had a thicker palisade mesophyll, (van de Vrie., 1972; Iskander et al., 2002; Abou Zaid et al., 2012).Although host plant 
resistance alone or in combination with other methods is environmentally safe and compatible with IPM, however this strategy is practical only when resistant varieties of crops are available and identified. Even a moderate level of resistance in a crop can have a positive impact and can reduce the number of pesticide applications (Srivastava, 1993).The present work was conducted to shade some light on the relative susceptibility of three eggplant cultivars, as well as the relationship between the level infestation of sucking pests and some phytochemical components of eggplant cultivars.

\section{MATERIALS AND METHODS}

\section{1-Cultivation of three eggplant cultivars for their relative susceptibility to some piercing-sucking pests.}

The abundance of T. urticae, A. gossypii, B. tabaci and Jassid, L.lybica on the eggplant cultivars (long black (ANAN), White long (Soma), Spherical black (Classic) was studied. An area of $1575 \mathrm{~m}^{2}$ was cultivated at Beni-Ady, Nasr District, Beni Suief Governorate, Egypt during two successive seasons 2013 and 2014. The nurseries of the cultivars were transported to hills in the permanent area on $15^{\text {th }}$ March during the two seasons. The experiment area was divided into 9 plots; each tested cultivar was represented by three replicates $\left(175 \mathrm{~m}^{2}\right)$ which were arranged in a randomized complete block design. Four weeks after transplantation from the nurseries and for 22 weeks later, samples of ten leaves representing all plant levels were weekly picked from each replicate (30 leaves for each cultivar). The collected leaves were placed directly into paper bags and taken to the laboratory. All movable stages of spider mite, T. urticae, aphid A. gossypii, Jassid, L. lybica and the immature stages of whitefly $B$. tabaci were counted using stereomicroscope.

\section{2-Effect of some phytochemical components on the infestation of} piercing sucking pests on different eggplant cultivars:-

Some specific chemical constituents of eggplant leaves of each cultivar were determined as follows:-

- Total protein content: To estimate protein content, the leaf nitrogen content was multiplied by 6.25 to obtain leaf content of protein as suggested by Pregl (1945).

- Total amino acids: were calorically assayed by ninhydrin reagent according to the method described by Lee and Takabashi (1966).

- Total carbohydrates: Total carbohydrates extracted from the plant leaves and prepared for assay according to Crompton and Birt (1967).

- Sodium content: Plant leaves were assayed for its sodium content according to the method described by Richards (1954).

- Potassium content: Plant leaves were assayed for its potassium content using the method described by Dewis and Freites (1970).

- Phosphorus content: the method suggested by Murphy and Riely (1962) was used to determine the phosphorus leaf content calorimetrically.

- Total calcium (e mail: bioanlab@bellsouth.net.palm city,USA)

- Total magnesium (mg) determination by the xylidyl blue method was followed using Quimica Clinica Aplicada S.A.kit (Spain) 
- Chloride content (CL) was detected using commercial Quimica Clinica Aplicada (43870 Amposta, Spain)

- Nitrogen content: leaves nitrogen content of the plant which was estimated according to the method described by Black (1965).

- Lipids content: Chemical analysis were carried out during the growing season of the three egg plant cultivars in leaf samples, during periods; the peak of infestation. Egg plant leaves were transferred to the laboratory and dried under room conditions, then transferred to physiological lab. Plant Protection Research Institute, A.R.C. for chemical analysis.

Statistical analysis: The statistical analysis (ANOVA) and Simple correlation of the obtained data were performed by using SAS program (SAS Institute, 1989) which run under WIN. Also the differences between means was conducted by using Duncan s multiple range test in this program.

\section{RESULTS AND DISCUSSION}

To evaluate the relative susceptibility of three eggplant cultivars to piercing sucking pests, the two spotted spider mite, Tetranychus urticae Koch, aphid, Aphis gossypii Glover, whitefly, Bemisia tabaci (Genn.) and Jassid, Empoasca lybica de-Berg infestation field were studied and phytochemical analysis of leaves were taken into consideration.

1-Field studies.

A- The two-spotted spider mite, T. urticae Koch.

As shown in Table (1) and statistical analysis revealed that there were highly significant differences between eggplant cultivars in their relative susceptibility to spider mite, $T$. urticae infestation during the two successive seasons 2013 and 2014, whereas population of mite started in few numbers after 30 days of sowing date on all tested cultivars with definite trend, whereby population increased gradually until reached its peak during the mid of July. Taha et al., (1995) found that there were relation between leaves constituents of soybean plants and spider mites level infestation. Iskader (2003) and Pravane et al., (2002) evaluated some eggplant varieties for their relative susceptibility to spider mite, T. urticae. Abou-Zaid et al., (2012) evaluated three eggplant cultivars to infestation with some piercing sucking pests. Obtained results revealed that Spherical black cultivar was the most susceptible to mite infestation which aggregated (370.4\&379.1) mite individuals / inch ${ }^{2}$ during the seasons 2013 and 2014, respectively. While, long black cultivar was highly tolerant to mite infestation than others, whereby, it received the average number $\left(48.4 \& 50.6\right.$ mites $/$ inch $\left.^{2}\right)$ at the same trend. The white long cultivar was intermediate in its relative susceptibility to spider mite, $T$. urticae infestation (Tables 1\&2).

\section{B- Aphid, Aphis gossypii Glover}

Aphis gossypii population started in few number in the early of April and May, then increased gradually in beginning of June till reached its peak at the end of July during the first season 2013 and middle of August during the second season 2014. 
Azouz, H. A. et al.

$1-$

998 
J. Plant Prot. and Path., Mansoura Univ., Vol. 5 (11), November, 2014

2

999 
As Duncan's multiple range test between the average number of aphid insects, it could be arranged into three different categories as the following; Spherical black was highly infested level (a) was represented by 119.16 individuals/leaf, followed by long black hybrid (83.39 individuals / leaf which occupied the intermediate level (b), while white long cultivar was the lowest infestation by aphid insects whereas, it harbored an average of (20.92 individuals / leaf), (Table 1). The same trend was recorded during the season 2014 (Table 2).

C- Whitefly, Bemisia tabaci (Genn.)

As shown in Tables (1\&2) obtained results revealed that the population density of whitefly $B$. tabaci started in few number in beginning of May reached the highest abundance at the end of June, and decreased to its minimum at early of August. Obtained data and statistical analysis showed that there were no significant difference between spherical black and white long cultivars (37.75 \&31.69) at the first season 2013 and (86.19\&76.82) individuals / leaf of the second season 2014, Tables (1\&2).

D- Jassid, Empoasca lypica de Berg

In Egypt, Jassid insects infestation becomes serious piercing sucking pest which causes extensive reduction in crop yield and quality especially in Beni-Suef Governorate which famous for medical and aromatically crops. The population curve of Jassid E. Iybica associated with tested eggplant cultivars. Tables (1\&2) showed almost the same trend during the two seasons 2013 \&2014. The white long cultivar aggregated the highest mean number (133.79\&155.49) individuals / leaf being significantly differ from long black cultivar which showed low infestation (118.68\&123.83) individuals / leaf during the two seasons 2013 \& 2014. These results coincide with that obtained by Yousafi et al., (2013).

\section{2- The relation between phytochemical components of eggplant leaves} and level infestation of some sap sucking pests.

The phenomenon of plant tolerance to pests is quality that enables the plant to avoid, tolerate or recover from the effect of pests that would cause greater damage to other varieties of the same species under similar conditions (Taha et al., 1995 \& El-Sanady et al., 2008).

Phytochemical components: total protein, total amino acids, total carbohydrates, total lipids and nitrogen were positively correlated with the different sucking pests, T. urticae, Aphis gossypii, B. tabaci and E. lybica associated with eggplant cultivars, while, the phytochemical constituents, potassium, sodium, calcium, phosphorus, magnesium and chloride were negatively correlated with sap sucking pests population as well as the level infestation. Obtained data in (Table 3) showed that spherical black cultivar classified as susceptible because of the total protein, total amino acids, total lipids, total carbohydrates and nitrogen were high in its leaves than that recorded in white long and long black cultivars which leaves content high of potassium, sodium, phosphorus, calcium, magnesium and chloride. These results agreement with that obtained by Banerjee and Raychaudhuri (1987) who found a significant correlation between nutrient content of leaves and reproductive potential of aphid insects. 
J. Plant Prot. and Path., Mansoura Univ., Vol. 5 (11), November, 2014

3

1001 
Azouz, H. A. et al.

$-4$ 
Tomocizyk and Kielkiewicz (2001) found that protein content decreased in the susceptible variety (Carona), while spider mite feeding decrease at protein content in Armis variety which was less susceptible. As shown in (Table 3 ) data and statistical analysis cleared that the total carbohydrate ranged between $38.02 \mathrm{mg} / \mathrm{gm}$ dry weight for the most susceptible spherical black cultivar to $24.5 \mathrm{mg} / \mathrm{gm}$ dry wt. for tolerance long black. While, potassium and sodium \% were high in long black and white long than spherical black (Table 3). Taha et al., (2002) found that, there was positive correlation between mite population and nitrogen, carbohydrate contents and negative correlation between the level infestation of spider mites and potassium and sodium contents. Hanafy (2004) stated that the relation of the movable stages of $T$. urticae and total protein, reduced and non- reduced sugars, phosphorus and carbohydrates were insignificant. Also, insignificant positive correlation values were detected between aphids population and each of total protein and carbohydrates.

\section{REFERENCES}

Abu-Zaid, A. M.; E.M. Bakr and N.A. Abd El-Hameed (2012): Abundance of three sap sucking pests on three eggplant cultivars with utilization of Phytoseiulus persimilis Athias-Henriot against Tetranychus urticae Koch, Acarines, 6: 49-53.

Banerjee, T. K. and D. Raychaudhuri (1987): Correlation of nutritional changes with the reproductive potential of Aphis gossypii Glover on egg plant. Proceedings: Animal Sciences. 9693): 239-244

Black, C. A. (1965): Methods of soil analysis. Part I and II. Amer. Soc.Lee,

Crompton, M. and I. M. Birt (1967): Changes in the amounts of carbohydrates, phosphagen, and related compounds during the metamorphosis of blowfly, Lucilia cuprina. J. Insect Physiol., 13: 15751595.

Dewis, J and E. Freites (1970): Physiological methods of soil and water analysis. Food Agric. Organization of the United Nations. Soils Bull., No. 10.

El-Sanady, M.A.; S. M. Soliman and Ahlam, A. Younis (2008): Field and laboratory studies to evaluate five soybean varieties for their relative susceptibility to the two spotted spider mite Tetranychus urticae Koch infestation (Acarina: Tetranychidae: Actenidida).Egypt. J. Agric. Res., 86 (1): 77-88.

FAO, 2012. FAOSTAT. Eggplant statistics (2010): Statistical Division, Food and Agriculture Organization of the United Nations.

Hanafy, A.R. I. (2004): Studies on the most important cucumber pests in the open field and suitable control programs. Ph. D. Thesis, Fac. Agric. Zagazig Univ., Benha Branch, 303 PP.

Iskander, A. K. (2003): Natural varietal resistance of some common eggplant, Solanum melongena $\mathrm{L}$. varieties against the two spotted spider mite, Tetranychus arabicus Attiah infestation under field conditions of Egypt. Minufia J Agric Res., 28 (6)" 1925-1938. 
Iskander, A. K.; H. M. El-Khateeb and N. H. Habashy (2002): Relative susceptibility of some pepper varieties to two spotted spider mite Tetranychus arabicus Attiah infestation under natural field conditions. $2^{\text {nd }}$ Inter.Conf. Plant Protect. Res. Institute,Cairo,21-24 Decemb.:28-32.

Lee, Y. P and T. Takabashi (1966): An improved colormetric determination of amino acids with the use of ninhydrin. Anal. Biochem., 14: 71-77.

Matsubara, K.; T. Kaneyuki: T. Miyake and M. Mori (2005): Antiangiogenic activity of nasunin, an antioxidant anthocyanin in eggplant peels. J. Agric. Fd. Chem., 53: 6272- 6275.

Murphy, J. and J. P. Riely (1962): A modified single solution for the determination of phosphate in nature water.Chem Acta, 26: 31-36.

Nonnecke, I.B.L., (1989): Vegetable production. Van Nostrand Reinhold, NY. pp.729.

Parvane, B. ; S. A. R. Pishes; M. A. Aikhadihe and E. Yadollah (2002):

Study on comparative resistance eggplant varieties to web spider mite (Tetranychus spp.) on different of eggplant varieties in Varamine region.

Citedhttp://agris.fao.org/agrissearch/search/dis[lay.do?f=2007\%FIR\%2 FIR0708.xmi\%3BIR20600192.

Pregl, E. (1945): Quantitative organic micro analysis. $4^{\text {th }}$ edit, Chundril, Ltd. London: $94-101$.

Richards, L. A. (1954): Diagnosis and improvement of saline and alkali soil. U.S. salinity lab. Staff, USA, Agriculture Hand Book No. 60.

SAS Institute (1989):SAS/Stat User's guide, 6.03 ed. SAS Institute, Cary, NC.S.

Srivastava, K. P. (1993): Chemical control of insect pest complex of brinjal. Entomon, 8: 97-100.

Taha, H.A. ; S. A. A. El-Rais; S. M. Soilman and A. A. Ahmed (2002): Field studies on spider mite Tetranychus urticae Koch as one of the main pest infesting oil crops. $2^{\text {nd }}$ Conf. Plant Prote. Res. Ins., Cairo, 21-24.

Taha, H. A. :R. A. Sedrak: R.A. Iskander and A.E. Sharaf (1995): Evaluation some soybean cultivars for their relative susceptibility to some pests and its relation of leaves contents with refer to their natural enemies. Egypt. J. Appl. Sci., 10 (6): 1-11.

Tindall, D. (1978): Commercial vegetables growing. ELBS \& Oxford University Press, London. pp. 711.

Tomczyk A. and M. Kielkiewicz (2001): Changes in content of proteins and free amino acids in the foliage of mite-infested glasshouse cucumber and tomato treated with plant growth-promoting rhizobacteria (PGPR). J. of Plant Prot. Res., 41, (1): 61-66.

van de Vrie, M., J. A. McMurtry, and C.B. Huffaker (1972): Ecology of tetranychid mites and their natural enemies: a review. III. Biology, ecology, and pest status, and host- plant relations of tetranychids. Hilgardia 41:343-432.

Yousafi,Q.; 1 M. Afzal; M. Aslam; M. Razaq and M. Shahid (2013): Screening of Brinjal (Solanum melongena L.) varieties Sown in Autumn for Resistance to Cotton Jassid, Amrasca bigutulla bigutulla (Ishida). Pakistan J. Zool., 45(4): 897-902. 


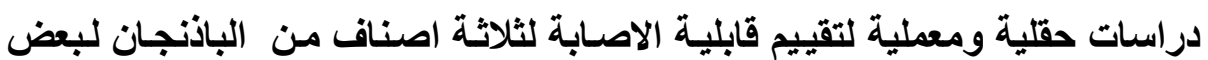

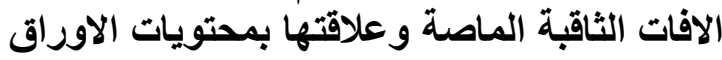

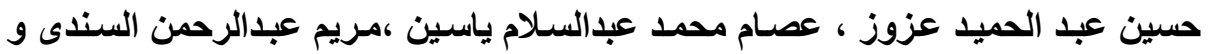
عزيزة محمود (بو زيلـ معهد بحوث وقاية النباتات ـ مركز البحوث الزراعية ـ الاقى ـ جيزة ـ مصر.

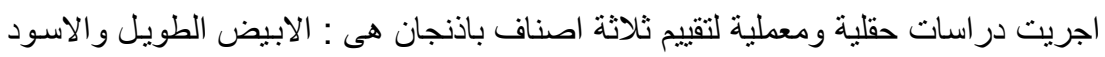

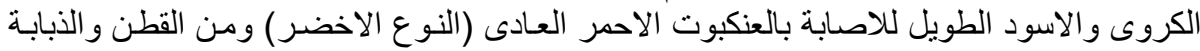

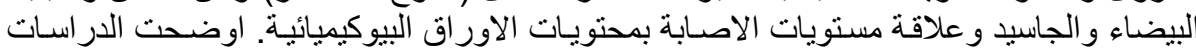

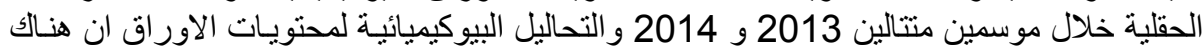

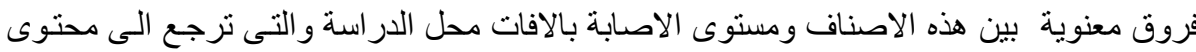

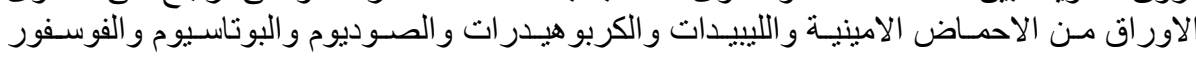

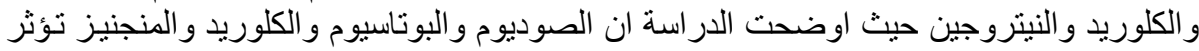

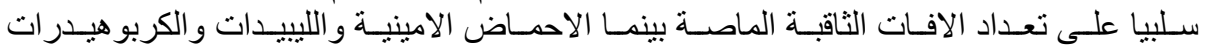

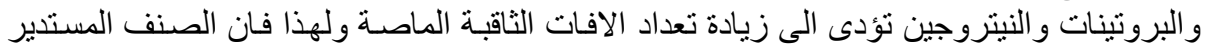

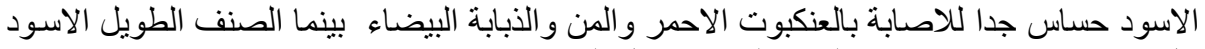
اقل الاصناف اصابة بالافات الثاقبة الماصة محل الاصدر الدراسة. 
J. Plant Prot. and Path., Mansoura Univ., Vol. 5 (11): 995 -1005, 2014

Table (1): Population density of the different piercing sucking pests on different eggplant cultivars at Beni-Sueif Governorate during 2013 cultivated season

\begin{tabular}{|c|c|c|c|c|c|c|c|c|c|c|c|c|}
\hline \multirow{2}{*}{$\begin{array}{c}\text { Sampling } \\
\text { dates }\end{array}$} & \multicolumn{3}{|c|}{ T.urticae } & \multicolumn{3}{|c|}{ A. gossypii } & \multicolumn{3}{|c|}{ B. tabaci } & \multicolumn{3}{|c|}{ E.lybica } \\
\hline & V1 & V2 & V3 & V1 & V2 & V3 & V1 & V2 & V3 & V1 & V2 & V3 \\
\hline $15 / 4 / 2013$ & 0.5 & 25.3 & 9.8 & 0.0 & 0.0 & 0.0 & 0.0 & 0.0 & 0.0 & 0.0 & 0.0 & 0.0 \\
\hline $30 / 4 / 2013$ & 5.5 & 65.3 & 31.8 & 0.0 & 0.0 & 0.0 & 0.0 & 7.5 & 0.0 & 0.0 & 0.0 & 0.0 \\
\hline $\mid 15 / 5 / 2013$ & 17.0 & 158.5 & 71.8 & 0.0 & 0.0 & 0.0 & 9.5 & 15.0 & 12.0 & 0.0 & 0.0 & 0.0 \\
\hline $30 / 5 / 2013$ & 31.5 & 333.3 & 199.3 & 5.0 & 0.0 & 12.0 & 30.5 & 31.0 & 30.5 & 11.5 & 0.0 & 0.0 \\
\hline $\mid 15 / 6 / 2013$ & 57.8 & 621.0 & 380.0 & 13.0 & 13.5 & 26.0 & 68.0 & 68.3 & 78.5 & 30.3 & 34.8 & 37.0 \\
\hline $30 / 6 / 2013$ & 88.5 & 671.5 & 496.8 & 21.8 & 38.5 & 58.0 & 121.8 & 116.3 & 130.0 & 65.3 & 64.5 & 69.3 \\
\hline $15 / 7 / 2013$ & 121.0 & 774.3 & 573.3 & 28.3 & 169.0 & 215.0 & 89.5 & 56.5 & 88.3 & 99.0 & 102.8 & 110.3 \\
\hline $30 / 7 / 2013$ & 93.8 & 560.0 & 486.0 & 54.0 & 351.0 & 334.3 & 43.5 & 14.0 & 34.0 & 193.3 & 200.5 & 215.0 \\
\hline $15 / 8 / 2013$ & 59.8 & 324.5 & 251.8 & 51.0 & 273.5 & 371.0 & 0.0 & 0.0 & 0.0 & 251.3 & 274.5 & 277.0 \\
\hline $30 / 8 / 2013$ & 23.3 & 193.8 & 124.3 & 35.5 & 71.8 & 225.5 & 0.0 & 0.0 & 0.0 & 303.8 & 316.3 & 338.8 \\
\hline $15 / 9 / 2013$ & 34.0 & 347.0 & 191.8 & 21.5 & 0.0 & 69.0 & 20. & 40.0 & 42.0 & 351.0 & 400.0 & 424.3 \\
\hline Mean & $48.4 \pm 11.83$ & $370.4 \pm 76.6^{\mathrm{a}}$ & $253.2 \pm 60.3^{b}$ & $20.92 \pm 5.95$ & $119.16 \pm 42.7^{2}$ & $83.4 \pm 37.8^{b}$ & $34.8 \pm 12.6^{a}$ & $31.7 \pm 13.2$ & $31.69 \pm 11.3$ & $118.7 \pm 40.2^{b}$ & $126.7 \pm 44.2^{\mathrm{a}}$ & $133.8 \pm 41.2^{2}$ \\
\hline L.S.D. & \multicolumn{3}{|c|}{42.51} & \multicolumn{3}{|c|}{25.66} & \multicolumn{3}{|c|}{4.78} & \multicolumn{3}{|c|}{8.40} \\
\hline
\end{tabular}

V1 = long black hybrid (ANAN F1) $\mathrm{V} 2=$ Spherical black (Classic) $\mathrm{V} 3=$ white long hybrid (Soma)

Means in the same raw followed by the same letters were not significantly differed at 0.05 level 
J. Plant Prot. and Path., Mansoura Univ., Vol. 5 (11), November, 2014

Table (2):Population density of the different piercing sucking pests on different eggplant cultivars at Beni-Sueif Governorate during 2014 cultivated season

\begin{tabular}{|c|c|c|c|c|c|c|c|c|c|c|c|c|}
\hline \multirow{2}{*}{$\begin{array}{c}\text { Sampling } \\
\text { dates }\end{array}$} & \multicolumn{3}{|c|}{ T.urticae } & \multicolumn{3}{|c|}{ A. gossypii } & \multicolumn{3}{|c|}{ B. tabaci } & \multicolumn{3}{|c|}{ E.lybica } \\
\hline & V1 & V2 & V3 & V1 & V2 & V3 & V1 & V2 & V3 & V1 & V2 & V3 \\
\hline $\mid 15 / 4 / 2014$ & 0.0 & 13.8 & 12.5 & 7.5 & 15.5 & 10.5 & 7.0 & 10.0 & 8.5 & 0.0 & 0.0 & 0.0 \\
\hline $30 / 4 / 2014$ & 3.0 & 67.0 & 35.3 & 15.8 & 66.0 & 60.8 & 17.5 & 21.0 & 21.3 & 0.0 & 0.0 & 0.0 \\
\hline $15 / 5 / 2014$ & 13.5 & 151.8 & 76.5 & $\begin{array}{ll}76.8 \\
\end{array}$ & 168.0 & 156.0 & 33.5 & 58.5 & 43.0 & 0.0 & 0.0 & 0.0 \\
\hline $30 / 5 / 2014$ & 31.3 & 349.8 & 215.0 & 34.8 & 63.5 & 61.8 & 86.3 & 152.0 & 137.5 & 17.3 & 16.3 & 20.3 \\
\hline $\mid 15 / 6 / 2014$ & 67.8 & 569.0 & 404.0 & 16.3 & 21.3 & 24.5 & 29.8 & 69.3 & 65.0 & 32.3 & 37.8 & 41.3 \\
\hline $30 / 6 / 2014$ & 84.5 & 743.3 & 537.5 & 29.8 & 35.0 & 45.3 & 11.0 & 25.0 & 30.8 & 65.5 & 45.5 & 70.3 \\
\hline $15 / 7 / 2014$ & 119.8 & 794.3 & 614.0 & 145.0 & 171.0 & 161.3 & 15.0 & 11.3 & 10.0 & 89.5 & 97.3 & 108.3 \\
\hline $30 / 7 / 2014$ & 129.5 & 644.8 & 577.3 & 213.0 & 343.0 & 313.8 & 14.0 & 69.0 & 47.3 & 194.5 & 212.3 & 253.3 \\
\hline $15 / 8 / 2014$ & 66.3 & 398.8 & 396.3 & 234.8 & 354.3 & 346.5 & 43.3 & 147.5 & 114.3 & 255.5 & 301.3 & 359.8 \\
\hline $30 / 8 / 2014$ & 29.8 & 246.5 & 241.8 & 117.3 & 181.0 & 173.5 & 86.5 & 172.0 & 169.0 & 314.5 & 365 & 397.8 \\
\hline \begin{tabular}{|l|}
$15 / 9 / 2014$ \\
\end{tabular} & 13.5 & 191.0 & 149.5 & 35.8 & 65.5 & 47.8 & 109.5 & 212.5 & 198.3 & 384 & 403.8 & 459.3 \\
\hline Mean & $50.82 \pm 13.8^{c}$ & $379.1 \pm 82.5^{\mathrm{a}}$ & $296.34 \pm 66.5^{b}$ & $84.3 \pm 24.7^{b}$ & $134.9 \pm 366^{a}$ & $127.4 \pm 34.8^{\mathrm{a}}$ & $41.2 \pm 10.8 \mathrm{~b}$ & $86.2 \pm 21.7^{a}$ & $76.8 \pm 20.2^{a}$ & $123.8 \pm 42.2^{b}$ & $134.5 \pm 7.3^{b}$ & $155.5 \pm 53.6$ \\
\hline L.S.D. & \multicolumn{3}{|c|}{45.38} & \multicolumn{3}{|c|}{12.33} & \multicolumn{3}{|c|}{9.40} & \multicolumn{3}{|c|}{17.92} \\
\hline
\end{tabular}

V1 = long black hybrid (ANAN F1) V2 = Spherical black (Classic) $\quad$ V3 = white long hybrid (Soma)

Means in the same raw followed by the same letters were not significantly differed at 0.05 level 
Azouz, H. A. et al.

Table (3): Phytochemical and biochemical analysis of leaves dry weight of three eggplant cultivars

\begin{tabular}{|c|c|c|c|c|c|c|c|c|c|c|c|}
\hline Variety & $\begin{array}{l}\text { Total } \\
\text { protein } \\
\text { mg/gm }\end{array}$ & \begin{tabular}{|} 
Total \\
amino \\
acids \\
$\mathrm{mg} / \mathrm{gm}$
\end{tabular} & $\begin{array}{l}\text { Total } \\
\text { lipids } \\
\text { mg/gm }\end{array}$ & $\begin{array}{c}\text { Total } \\
\text { carbohydrates } \\
\%\end{array}$ & $\begin{array}{c}\text { Sodium } \\
\text { content } \\
\%\end{array}$ & $\begin{array}{c}\text { Potassium } \\
\text { content } \\
\%\end{array}$ & $\begin{array}{c}\text { Total } \\
\text { phosphorus } \\
\%\end{array}$ & $\begin{array}{c}\text { Calcium } \\
\text { content } \\
\%\end{array}$ & $\begin{array}{c}\text { Magnesium } \\
\text { content } \\
\%\end{array}$ & $\begin{array}{c}\text { Chloride } \\
\text { content } \\
\%\end{array}$ & $\begin{array}{l}\text { Nitrogen } \\
\text { content }\end{array}$ \\
\hline $\begin{array}{l}\text { Spherical black } \\
\text { (Classic) }\end{array}$ & 142.33 & 34.26 & 18.64 & 38.02 & 25.66 & 355.0 & 903 & 551.3 & 902.0 & 325 & 44.1 \\
\hline $\begin{array}{l}\text { White long } \\
\text { (Soma) }\end{array}$ & 109.66 & 26.43 & 18.65 & 26.08 & 34.33 & 418.0 & 1160 & 662.3 & 930.6 & 630.3 & 17.8 \\
\hline $\begin{array}{l}\text { Long black } \\
\text { (Anan F1) }\end{array}$ & 82.33 & 22.90 & 12.39 & 24.5 & 97.66 & 550.0 & 1206 & 1169.0 & 1031.3 & 654.6 & 13.4 \\
\hline
\end{tabular}


J. Plant Prot. and Path., Mansoura Univ., Vol. 5 (11), November, 2014

Table (4): Correlation coefficient $(r)$ between chemical composition of leaves and abundance of piercing sucking

\begin{tabular}{|c|c|c|c|c|c|c|c|c|c|c|c|c|}
\hline \multirow[b]{2}{*}{ Pests } & \multirow[b]{2}{*}{ Varity } & \multicolumn{11}{|c|}{ Phytochemical components } \\
\hline & & $\begin{array}{l}\text { Total } \\
\text { protein }\end{array}$ & $\begin{array}{l}\text { Total } \\
\text { amino } \\
\text { acids }\end{array}$ & $\begin{array}{l}\text { Total } \\
\text { lipids }\end{array}$ & $\begin{array}{c}\text { Total } \\
\text { carbohydrates }\end{array}$ & $\begin{array}{l}\text { Sodium } \\
\text { content }\end{array}$ & $\begin{array}{c}\text { Potassium } \\
\text { content }\end{array}$ & $\begin{array}{c}\text { Total } \\
\text { phosphorus }\end{array}$ & Calcium & $\begin{array}{c}\text { Magnesium } \\
\text { content }\end{array}$ & $\begin{array}{l}\text { Chloride } \\
\text { content }\end{array}$ & $\begin{array}{l}\text { Nitrogen } \\
\text { content }\end{array}$ \\
\hline \multirow{3}{*}{ E. lybica } & V1 & 0.994 & 0.872 & 0.931 & 0.389 & -0.882 & -0.371 & -0.911 & -0.411 & -0.962 & 0.551 & 0.615 \\
\hline & V2 & 0.272 & 0.134 & 0.264 & 0.184 & 0.068 & -0.608 & 0.041 & 0.189 & -0.838 & 0.931 & 0.936 \\
\hline & V3 & 0.929 & 0.614 & 0.733 & -0.995 & -0.047 & -0.482 & -0.978 & 0.690 & 0.444 & -0.602 & 0.999 \\
\hline \multirow{3}{*}{ B.tabaci } & V1 & 0.779 & 0.273 & 0.917 & 0.375 & -0.957 & -0.392 & -0.355 & 0.351 & -0.874 & 0.199 & -0.120 \\
\hline & V2 & 0.076 & 0.066 & 0.068 & 0.375 & 0.264 & -0.753 & 0.238 & 0.009 & 0.714 & 0.985 & 0.987 \\
\hline & V3 & 0.655 & 0.543 & 0.401 & -0.228 & -0.928 & -0.669 & 0.123 & 0.456 & 0.991 & 0.556 & 0.295 \\
\hline \multirow{3}{*}{ A. gossypii } & $\mathrm{V} 1$ & 0.998 & 0.854 & 0.944 & -0.354 & -0.899 & -0.337 & -0.895 & -0.377 & -0.972 & -0.519 & 0.585 \\
\hline & $\mathrm{V} 2$ & 0.199 & 0.335 & 0.207 & 0.614 & 0.517 & -0.904 & 0.494 & 0.282 & 0.496 & -0.995 & 0.933 \\
\hline & V3 & 0.794 & 0.362 & 0.208 & $\begin{array}{l}-0.420 \\
\end{array}$ & -0.833 & -0.505 & 0.321 & 0.267 & $\begin{array}{l}-0.997 \\
\end{array}$ & 0.377 & 0.482 \\
\hline \multirow{3}{*}{ T. urticae } & V1 & 0.613 & 0.043 & 0.800 & 0.579 & -0.865 & -0.594 & -0.129 & 0.599 & -0.738 & 0.420 & 0.347 \\
\hline & V2 & 0.802 & 0.999 & 0.616 & 0.804 & $\begin{array}{l}-0.519 \\
\end{array}$ & 0.793 & 0.994 & 0.818 & 0.689 & -0.899 & 0.931 \\
\hline & V3 & 0.455 & 0.982 & 0.999 & -0.817 & -0.694 & -0.939 & -0.874 & -0.996 & 0.251 & -0.979 & 0.775 \\
\hline
\end{tabular}

V1 = Spherical black (Classic) $\quad$ V2 = White long hybrid (Soma) $\quad$ V3 = long black hybrid (ANAN F1) 
Azouz, H. A. et al.

1010 